\title{
Effects of estradiol and FSH on leptin levels in women with suppressed pituitary
}

\author{
Selmo Geber ${ }^{1,2^{*}}$, Augusto HF Brandão ${ }^{2}$ and Marcos Sampaio ${ }^{1}$
}

\begin{abstract}
Background: Female fertility depends on adequate nutrition and energy reserves, suggesting a correlation between the metabolic reserve and reproductive capacity. Leptin regulates body weight and energy homeostasis. The aim of this study was to investigate whether estradiol or FSH alone has a direct effect on the production of leptin.

Methods: A total of 64 patients submitted to controlled ovarian hyperstimulation with recombinant FSH for assisted reproduction and 20 patients using estradiol valerate for endometrial preparation for oocyte donation treatment were included in the study. All patients used GnRH analogues before starting treatment to achieve pituitary suppression. Blood samples for hormonal measurements were collected before starting and after completing the respective treatments. Data were analyzed statistically by the chi-square test, Student's t-test and Pearson's correlation test.
\end{abstract}

Results: We observed an elevation of serum leptin levels secondary to the increase in estradiol, in the absence of influence of any other ovarian or pituitary hormone. The rising rate of leptin levels was higher in women treated with recombinant FSH, which also had higher levels of estradiol, than in those treated with estradiol valerate.

Conclusions: This study demonstrates a correlation between serum levels of estradiol and leptin, suggesting that estradiol is an important regulator of leptin production and that its effects can be amplified by its association with FSH.

Keywords: Leptin, Estradiol, Follicle stimulating hormone

\section{Background}

The relationship between body fat and the reproductive process has been studied for many years. Fertility depends on a correct nutrition and energy reserves, what creates a correlation between the metabolic reserve and reproductive capacity [1]. Women with extreme dietetic restrictions and those who are overweight show alterations in the reproductive axis. Obese women also have an early menarche than those with normal weight. This can be explained by the fact that menstrual cycle initiates only when the body weight reaches a critical mass, around $48 \mathrm{Kg}$ or contains approximately $22 \%$ of body fat and obese women enter this critical weight range at a younger age [2]. Irregular menstrual cycles are frequent

\footnotetext{
* Correspondence: selmogeber@origen.com.br

'Origen, Center for Reproductive Medicine, Avenida do Contorno 7747, Lourdes, CEP, 30110120, Belo Horizonte, MG, Brazil

${ }^{2}$ Medical School of the Universidade Federal de Minas Gerais, Belo Horizonte, Brazil
}

\section{Biomed Central}

(c) 2012 Geber et al.; licensee BioMed Central Ltd. This is an Open Access article distributed under the terms of the Creative Commons Attribution License (http://creativecommons.org/licenses/by/2.0), which permits unrestricted use, distribution, and reproduction in any medium, provided the original work is properly cited. among women too thin, those with eating disorders such as bulimia or nervous anorexia and athletes submitted to long-term exercises [3].

Leptin is a protein codified by the obesity gene (ob), secreted by the adipocytes [4], which acts in the Central Nervous System as a signal to regulate body weight and energy homeostasis [5,6]. Initially, leptin was considered an anti-obesity hormone [7], but experimental evidences have shown that this molecule also participates in many metabolic and endocrine processes, including the reproductive function $[8,9]$. The presence of leptin receptors at all levels of the hypothalamic-pituitary-ovarian axis indicates a correlation between nutrition and reproduction, possibly through complex paracrine and/or endocrine interactions [10].

Although leptin receptors have been demonstrated in human ovaries, there is no information concerning leptin effects on follicular cells [11]. Contradictory results 
have been reported concerning the effects of estradiol and follicle-stimulating hormone (FSH) on leptin production by adipocytes [12-15]. Therefore the aim of this study was to investigate whether estradiol or FSH has a direct effect on the production of leptin.

\section{Methods \\ Patients}

This prospective study included a total of 84 patients who underwent infertility treatment through assisted reproduction technique at ORIGEN, Centre of Reproductive Medicine, Belo Horizonte, Brazil. This study was approved by our local ethics committee, according to Brazilian ethics and legal regulation, and all patients signed an Informed Consent Form. Patients with tubal or male factor infertility who had serum FSH concentrations $<15 \mathrm{IU} / \mathrm{l}$ on day 3 of the menstrual cycle were submitted to controlled ovarian superovulation for IVF/ICSI (GnRHa/FSH Group) $(n=64)$. Patients with poor ovarian reserve, i.e., with serum FSH concentrations $>15$ IU/ 1 and serum estradiol levels $<60 \mathrm{pg} / \mathrm{ml}$ on day 3 of the menstrual cycle were submitted do oocyte donation (OD) treatment ( $\mathrm{GnRHa} / \mathrm{E}_{2}$ Group) $(\mathrm{n}=20)$. Patients with endocrine disorders were not included. Body Mass Index (BMI) was calculated using the patient's body weight $(\mathrm{Kg})$ divided by the square of their height (meters). Women were considered obese when BMI was $>30 \mathrm{~kg} / \mathrm{m}^{2}$. All patients had normal glucose levels.

\section{Controlled ovarian stimulation}

All patients of group 1 (GnRHa/FSH) submitted to IVF/ ICSI had the same long protocol for controlled ovarian stimulation using the same hormones and the same criteria for dose tailoring. Treatment started with subcutaneous administration of $3.6 \mathrm{mg}$ of GnRHa (Goserelin, Zoladex; Zeneca, Brazil) for suppression of pituitary function on day 2 of the menstrual cycle. To confirm pituitary down-regulation, serum estradiol $\left(\mathrm{E}_{2}\right)$ levels and vaginal ultrasound were performed $\sim 10$ days later. If the estradiol concentration was $<30 \mathrm{pg} / \mathrm{ml}$ and the ultrasound showed an endometrial thickness of $<3 \mathrm{~mm}$, pituitary suppression was confirmed. Otherwise, serum estradiol and vaginal ultrasound were repeated every other day until suppression was achieved [16].

After confirmation of suppression, patients were superovulated with daily subcutaneous injections of recombinant FSH (rFSH - GonalF - Serono - Brazil). The starting dose of rFSH was defined according to patient's age, i.e., 225 IU for $<35$ years old, 300 IU for 35 to 37 years old and $375 \mathrm{IU}$ for $>37$ years old. The dose was adjusted according to the ovarian response measured by $E_{2}$ levels and follicular growth monitored by vaginal ultrasound (Tosbee- Toshiba- Japan). Recombinant hCG (rhCG- 250 mcg - Ovidrel - Serono - Brazil) was given when at least two follicles reached a mean size of $17 \mathrm{~mm}$ with corresponding $\mathrm{E}_{2}$ levels $(\sim 200 \mathrm{pg} / \mathrm{mL}$ per follicle) [17]. Oocyte retrieval was performed $\sim 34$ hours after rhCG injection by vaginal ultrasound guided aspiration.

\section{Endometrial preparation}

All patients in group $2\left(\mathrm{GnRHa} / \mathrm{E}_{2}\right)$ submitted to oocyte donation had the same endometrial preparation. Treatment started with pituitary suppression, as described for patients in group 1 (GnRHa/FSH). After pituitary downregulation was confirmed, estradiol valerate $\left(\mathrm{E}_{2} \mathrm{~V}\right.$ - Primogyna - Bayer - Brazil) was given to the patients for endometrial preparation. Patients started with $2 \mathrm{mg} /$ day from day $1-5$, then the dose was increased to $4 \mathrm{mg} /$ day from day $6-10$, and increased to $6 \mathrm{mg} /$ day from day 11 until 12 weeks of pregnancy. After 15 days of treatment, endometrial preparation was confirmed if $E_{2}$ levels were $>250 \mathrm{pg} / \mathrm{ml}$ and vaginal ultrasound showed an endometrial thickness $>8 \mathrm{~mm}[18]$.

\section{Hormone assays}

Blood samples for FSH, estradiol and leptin measurements were collected between 8:00 and 10:00 am. The first collection occurred on the day pituitary suppression was confirmed for both groups. For patients of group 1, the second blood collection was performed on the last day of controlled ovarian stimulation, i.e., when patients presented the maximum serum levels of estradiol. For patients of group 2, the second blood collection was performed on the day of the insemination (IVF or ICSI), i. e., when they had maximum serum levels of estradiol, and before progesterone administration.

For FSH measurements we used immunometric assays based on enhanced luminescence (AmerliteFSH assay Amersham International plc - UK). The inter- and intra-assay coefficients of variation were 7.5 and $6.0 \%$ respectively. The results were expressed as IU/l. Estradiol was measured using a competitive immunoassay based on enhanced luminescence (AmerliteEstradion-60 assay; Amersham International). The results were expressed as $\mathrm{pg} / \mathrm{ml}$. The inter- and intra-assay coefficients of variation were 9.1 and $8.0 \%$ respectively.

Leptin was measured in all serum samples in duplicate using a radioimmunoassay method and all samples were assayed in the same batch. The kits (Linco Research - St Charles - USA) contained human leptin antibody prepared in rabbit and raised against highly purified human leptin and standards and tracer prepared with human leptin. The results were expressed as $\mathrm{ng} / \mathrm{ml}$. The inter- and intra-assay coefficients of variation were 6.2 and $7.1 \%$ respectively.

\section{Statistics}

Shapiro-Wilk test was used to assess the normality of continuous data. The Chi-square test was applied to 
Table 1 Patient characteristics according to the type of hormonal treatment

\begin{tabular}{llll}
\hline & $\mathbf{G n R H a} / \mathbf{F S H n}=\mathbf{6 4}$ & $\mathbf{G n R H a} / \mathbf{E}_{\mathbf{2}} \mathbf{n}=\mathbf{2 0}$ & $\mathbf{p}$ \\
\hline Age (years) & $34.3 \pm 3.7(27-42)$ & $42 \pm 4.8(31-50)$ & $0.0001^{\mathrm{a}}$ \\
BMl $\left(\mathrm{Kg} / \mathrm{m}^{2}\right)$ & $23 \pm 5.1$ & $23.3 \pm 4.1$ & $0.25^{\mathrm{a}}$ \\
Obese & $17.2 \%$ & $15 \%$ & $0.24^{\mathrm{b}}$
\end{tabular}

Values are expressed in mean $\pm s d$ (range).

${ }^{\text {a }}$ Student's $t$ test for paired samples.

${ }^{\mathrm{b}}$ chi-square test.

compare categorical variables between the two groups of patients. Mann-Whitney's test was performed to compare the medians of BMI, estradiol, leptin, and leptin rate. The Pearson correlation test was used to assess the relationship between the hormones. We calculated the leptin rate (LR) as follows: $\mathrm{LR}=\mathrm{LA} / \mathrm{LB} \times 100$, where $\mathrm{LA}$ corresponds to the leptin levels after treatment and LB to the leptin levels before treatment. Differences were considered significant when $\mathrm{p}<0.05$. Descriptive data were expressed as mean \pm SD or as median (interquartile range) for normally and non-normally distributed data, respectively.

\section{Results}

All 84 patients selected in this study completed the treatment and had no adverse effects. The mean age $( \pm$ SD) of the patients submitted to IVF/ICSI was $34.3 \pm 3.7$ years (range $27-42$ ) and for the patients submitted to OD was $42 \pm 4.8$ years (range $31-50$ ). In the GnRHa/FSH group the mean BMI was $23 \pm 5.1$ and 11 patients $(17.2 \%)$ were obese, in the $\mathrm{GnRHa} / \mathrm{E}_{2}$ group the mean BMI was $23.3 \pm 4.1$ and 3 patients (15\%) were obese (Table 1).

When we compared the serum leptin levels according to the BMI, we observed that leptin levels were significantly higher in obese than in non-obese patients, both before $(10.9 \pm 3.3$ and $8.8 \pm 4.2$, respectively $-\mathrm{p}=0.017)$ and after treatment $(26.3 \pm 11.7$ and $13.5 \pm 7.5$, respectively $-\mathrm{p}=0.0047$ ).

In both $\mathrm{GnRHa} / \mathrm{FSH}$ and $\mathrm{GnRHa} / \mathrm{E}_{2}$ groups, both serum estradiol and leptin levels were significantly higher after than before starting treatment (Table 2). Leptin levels presented by these groups were similar, both before and after treatment $(\mathrm{p}=0.8$ and 0.7 , respectively). Estradiol levels measured after treatment were significantly higher in the GnRHa/FSH group than in the $\mathrm{GnRHa} / \mathrm{E}_{2}$ group ( $\mathrm{p}=0.009$ ) (Table 1).

Pearson's correlation analysis demonstrated significant correlation between FSH or estradiol, and leptin serum levels. Correlation coefficients of 0.72 and 0.92 were observed for the serum levels of leptin detected before and after treatment in the GnRHa/FSHgroup and in the $\mathrm{GnRHa} / \mathrm{E}_{2}$ group, respectively. Also, this result shows that the final levels of leptin are directly related to the initial ones.

The leptin rate was calculated to evaluate the rising rate of leptin levels from the first to the second analysis. We detected similar leptin rates between obese and non-obese patients $(167.4 \pm 93.4$ and $158 \pm 48.9$, respectively). The mean leptin rate in the $\mathrm{GnRHa} / \mathrm{FSH}$ group was 159.6 \pm 58.1 (range $74.2-408.8$ ) and $136.7 \pm 34.2$ (range 65.4 - 213.7) in the $\mathrm{GnRHa} / \mathrm{E}_{2}$ group. The difference between these groups was statistically significant $(\mathrm{p}=0.0034)$, demonstrating a higher rate of increase in leptin levels in the GnRHa/FSH group.

\section{Discussion}

Evidences have suggested a relationship between leptin and the hormones of hypothalamic - pituitary- ovarian axis [9,19-21]. In this study, we analyzed the relationship between leptin and estradiol and FSH, in the absence of interferences of other pituitary and ovarian hormones, due to suppression of pituitary function after administration of GnRHa.

Patients selected in this study were submitted to controlled ovarian hyperstimulation for in vitro fertilization treatment (GnRHa/FSH group) or to oocyte donation treatment (GnRHa/E $\mathrm{E}_{2}$ group). As expected, patients included in the $\mathrm{GnRHa} / \mathrm{E}_{2}$ group had had higher mean age. These patients were enrolled in a program of egg donation due to the history of low or no ovarian response, usually associated with the increase of age.

Regarding obesity, the two groups showed the same proportion of obese patients, thus excluding bias for comparison between them. When we evaluated the variation in leptin levels according to BMI, the results showed that obese patients had serum leptin levels significantly higher than those of non-obese, both before and after treatment.

Table 2 Serum Leptin and estradiol levels measured before and after treatment

\begin{tabular}{llllll}
\hline & Leptin before treatment & Leptin after treatment & $\mathbf{p}$ & $\mathbf{E}_{\mathbf{2}}$ before treatment & $\mathbf{E}_{\mathbf{2}}$ after treatment \\
\hline $\mathrm{GnRHa} / \mathrm{FSH}$ & $10.4 \pm 6.8$ & $15.7 \pm 9.6$ & 0.0001 & $16.8 \pm 7.8$ & $1440.4 \pm 1122.6$ \\
$\mathrm{n}=64$ & $(2.1-45)$ & $(4.6-46.2)$ & & $(9-29)$ & $(200-5150)$ \\
$\mathrm{GnRHa} / \mathrm{E}_{2}$ & $11.1 \pm 9,9$ & $14.5 \pm 12.51$ & 0.0079 & $13.0 \pm 6,6$ & 9.0001 \\
$\mathrm{n}=20$ & $(2.3-40.4)$ & $(3-53.8)$ & & $(9-29)$ & $(108-2306)$ \\
\hline
\end{tabular}

Values are expressed as mean $\pm \mathrm{sd}$ (range).

Data were analyzed using Student's $t$ test for paired samples. 
These results are in accordance to those reported previously [22]. Although the mean age of both groups was different, it has been previously demonstrated that there is no difference in levels of serum leptin between young and postmenopausal women [23].

Pre-treatment and post-treatment evaluations showed that serum levels of estradiol significantly increased in both groups after treatment. These results were expected, since patients presented hypoestrogenism before treatment due to the use of $\mathrm{GnRH}$ analogue and after were submitted to controlled ovarian stimulation or to the use of estradiol for endometrial preparation. When comparing the serum levels of estradiol detected after treatment in the two groups, we observed significantly higher levels in the GnRHa/FSH group, due to the response to the ovarian stimulation. In the GnRHa/ $\mathrm{E}_{2}$ group, patients received fixed doses of estradiol valerate, thus the levels of estradiol detected in serum reach a threshold corresponding to the administered dose.

It is not a consensus whether estradiol interfere with leptin levels. Some studies show that estradiol increases leptin levels in women with normal menstrual cycles [24]. In another study it is shown that estrogen therapies in postmenopausal subjects do not influence serum leptin concentrations [25], and in patients with PCOS, ethinyl estradiol and drospirenone do not increase leptin levels for a 3-month period [26].

With regard to the evaluation of leptin, we also observed a significant increase in its serum levels after treatment, in both groups. These findings demonstrate, for the first time, an elevation of serum leptin levels secondary to the increase in estradiol, in the absence of influence of any other ovarian or pituitary hormone (GnRH dependent), suggesting a direct correlation between these hormones and a role of estradiol in stimulating the production or the release of leptin. We hypothesize that an increase in ob gene (responsible for leptin synthesis by adipocytes) expression induced by estradiol could be the responsible for these results. Another possible mechanism is a leptin gene promoter activation through selective regulation via estrogen receptors [27].

Similar results have already been obtained with women submitted to controlled ovarian stimulation for IVF without the use of GnRHa [20,28,29]. However, differently from our work in which women had pituitary suppression, patients included in these studies were subjected to the influence of ovarian and pituitary hormones, which could interfere with or bias the results.

Although serum levels of leptin were similar in both groups after treatment, the leptin rate was significantly higher in the group of patients treated with rFSH when compared to the group treated with estradiol. This result can be explained by the higher levels of estradiol observed in this group after treatment. However, we cannot exclude the possibility of a direct action of FSH on the production of leptin, through a possible ovarian production or an indirect interference in the synthesis of this hormone by adipocytes, through other ovarian substances [30].

This issue is, however, subject of controversy. On the one hand, it has been shown that leptin levels of women in menopause are lower than those of women in menacme [31]. As in menopause endogenous levels of $\mathrm{FSH}$ are very high, these data raise doubt as to whether FSH indeed stimulates the production of leptin. On the other hand, other authors [11,30,32] showed the presence of leptin receptor in ovarian follicles, and the expression of leptin mRNA in granulosa and cumulus oophorus cells. It is possible that the influence of FSH on the ovarian production of leptin occurs only in the presence of follicles, thus not occurring in menopause.

\section{Conclusions}

This study demonstrates a strong correlation between serum levels of estradiol and leptin, suggesting that estradiol is an important regulator of leptin production. These results may contribute to a better understanding of the interaction between metabolic processes and phenomena involved in reproduction. Further investigation is required to establish the role of FSH on the raising of leptin levels.

\section{Competing interests}

The authors declare that they have no competing interests

\section{Authors' contributions}

SG and MS contributed to the conception and study design, collected the data, performed the interpretation of the data and wrote and approved the final version of the manuscript. AHFB contributed to the interpretation of the data and in the writing of the manuscript. All authors read and approved the final manuscript.

Received: 6 April 2012 Accepted: 29 May 2012

Published: 15 June 2012

\section{References}

1. Barash IA, Cheung CC, Weigle DS, Ren H, Kabigting EB, Kuijper $J L$, Clifton DK, Steiner RA: Leptin is a metabolic signal to the reproductive system. Endocrinology 1996, 137:3144-3147.

2. Bray GA: Obesity and reproduction. Hum Reprod 1997, 12:26-32.

3. Abraham SF, Beumont PJ, Fraser IS, Llewellyn-Jones D: Body weight, exercise and menstrual status among ballet dancers in training. $\mathrm{Br} \mathrm{J}$ Obstet Gynaecol 1982, 89:507-510.

4. Zhang Y, Proença R, Maffei M, Barone M, Leopold L, Friedman JM: Positional cloning of the mouse obese gene and its human homologue. Nature 1994, 372:425-432.

5. Campfield LA, Smith FJ, Guisez Y, Devos R, Burn P: Recombinant mouse OB protein: Evidence for a peripheral signal linking adiposity and central neural networks. Science 1995, 269:546-549.

6. Pelleymounter MA, Cullen MJ, Baker MB, Hecht R, Winters D, Boone T, Collins F: Effects of the obese gene product on body weight regulation in ob/ob mice. Science 1995, 269:540-542.

7. Spicer LJ, Francisco CC: The adipose obese gene product, leptin. Endocrinology 1997, 138:3374-3379.

8. Clarke IJ, Henry BA: Leptin and reproduction. Rev Reprod 1999, 4:48-55. 
9. Cunningham MJ, Clifton DK, Steiner RA: Leptin's actions on the reproductive axis: perspectives and mechanisms. Biol Reprod 1999 60:216-222

10. Cervero A, Domínguez F, Horcajadas JA, Quiñonero A, Pellicer A, Simón C: The role of the leptin in reproduction. Curr Opin Obstet Gynecol 2006, 18:297-303.

11. Karlsson C, Lindell K, Svensson E, Bergh C, Lind P, Billig H, Carlsson LM, Carlsson B: Expression of functional leptin receptors in the human ovary. J Clin Endocrinol Metab 1997, 82:4144-4148.

12. Bouvattier C, Lahlou N, Roger M: Hyperleptinaemia is associated with impaired gonadotrophin responses to $\mathrm{GnRH}$ during late puberty in obese girls, not boys. Eur J Endocrinol 1998, 138:653-658.

13. Riad-Gabriel MG, Jinagouda SD, Sharma A: Changes in plasma leptin during the menstrual cycle. Eur J Endocrinol 1998, 139:528-531.

14. Messinis IE, Milingos SD, Alexandris E, Kariotis I, Kollios G, Seferiadis K: Leptin concentrations in normal women following bilateral ovariectomy. Hum Reprod 1999, 4:913-918.

15. Rechberger T, Baranowski W, Postawski K: Serum leptin concentrations in women taking oral contraceptives. Eur J Obstet Gynecol Reprod Biol 1999, 83:105-108.

16. Geber S, Sales L, Sampaio M: Comparison between a single dose of goserelin (depot) and multiple daily doses of leuprolide acetate for pituitary suppression in IVF treatment: a clinical endocrinological study of the ovarian response. J Assist Reprod Genet 2002, 19:313-318.

17. Geber S, Ferreira DP, Spyer Prates LF, Sales L, Sampaio M: Effects of previous ovarian surgery for endometriosis on the outcome of assisted reproduction treatment. Reprod Biomed Online 2002, 5:162-166.

18. Sampaio A, Geber S: Births after transfer of zona-free blastocysts in oocyte donation cycles. J Assist Reprod Genet 2001, 18:156-159.

19. Yu WH, Kimura M, Walczewska A, Karanth S, McCann SM: Role of leptin in hypothalamic-pituitary function. Proc Natl Acad Sci U S A 1997, 94:10231028.

20. Messinis IE, Milingos S, Zikopoulos K, Kollios G, Seferiadis K, Lolis D: Leptin concentrations in the follicular phase of spontaneous cycles and cycles superovulated with follicle stimulating hormone. Hum Reprod 1998 13:1152-1156

21. Nagatani S, Guthikonda P, Thompson RC, Tsukamura H, Maeda Kl, Foster DL: Evidence for $\mathrm{GnRH}$ regulation by leptin: leptin administration prevents reduced pulsatile LH secretion during fasting. Neuroendocrinology 1998, 67:370-376.

22. Considine RV, Sinha MK, Heiman ML, Kriauciunas A, Stephens TW, Nyce MR, Ohannesian JP, Marco CC, McKee LJ, Bauer TL, et al: Serum immunoreactive-leptin concentrations in normal-weight and obese humans. N Engl J Med 1996, 334:292-295.

23. Castracane VD, Kraemer RR, Franken MA, Kraemer GR, Gimpel T: Serum leptin concentration in women: effect of age, obesity, and estrogen administration. Fertil Steril 1998, 70:472-477.

24. Lin KC, Sagawa N, Yura S, Itoh H, Fujii S: Simultaneous increases of leptin and gonadotropin-releasing hormone following exogenous estrogen administration in women with normally menstrual cycle. Endocr J 2005, 52:449-454

25. Bednarek-Tupikowska G, Filus A, Kuliczkowska-Płaksej J, Tupikowski K, Bohdanowicz-Pawlak A, Milewicz A: Serum leptin concentrations in preand postmenopausal women on sex hormone therapy. Gynecol Endocrinol 2006, 22:207-212.

26. Sağsöz N, Orbak Z, Noyan V, Yücel A, Uçar B, Yildiz L: The effects of oral contraceptives including low-dose estrogen and drospirenone on the concentration of leptin and ghrelin in polycystic ovary syndrome. Fertil Steril 2009, 92:660-666.

27. O'Neil JS, Burow ME, Green AE, McLachlan JA, Henson MC: Effects of estrogen on leptin gene promoter activation in MCF-7 breast cancer and JEG-3 choriocarcinoma cells: selective regulation via estrogen receptors alpha and beta. Mol Cell Endocrinol 2001, 176:67-75.

28. Strowitzki T, Kellerer M, Capp E: Increase in serum leptin concentrations in women undergoing controlled ovarian hyperstimulation for assisted reproduction. Gynecol Endocrinol 1998, 12:167-169.

29. Zhao Y, Kreger DO, Brannian JD: Serum leptin concentrations in women during gonadotropin stimulation cycles. J Reprod Med 2000, 45:121-125.
30. Cioffi JA, Van Blerkom J, Antczak M, Shafer A, Wittmer S, Snodgrass HR: The expression of leptin and its receptors in pre-ovulatory human follicles. Mol Hum Reprod 1997, 3:372-467.

31. Rosenbaum M, Nicolson M, Hirsch J, Heymsfield SB, Gallagher D, Chu F, Leibel RL: Effects of gender, body compostion, and menopause on plasama concentrations of leptin. J Clin Endocrinol Metab 1996, 81:3424-3427.

32. Abir R, Ao A, Jin S, Raanani H, Ben-Haroush A, Fisch B: Leptin and its receptors in human fetal and adult ovaries. Fertil Steril 2005, 84:1779-1782.

doi:10.1186/1477-7827-10-45

Cite this article as: Geber et al:: Effects of estradiol and FSH on leptin levels in women with suppressed pituitary. Reproductive Biology and Endocrinology 2012 10:45.

\section{Submit your next manuscript to BioMed Central and take full advantage of:}

- Convenient online submission

- Thorough peer review

- No space constraints or color figure charges

- Immediate publication on acceptance

- Inclusion in PubMed, CAS, Scopus and Google Scholar

- Research which is freely available for redistribution

Submit your manuscript at www.biomedcentral.com/submit
C Biomed Central 